\title{
Feminist Foreign Policy Studies in Europe
}

\author{
Jennifer Thomson
}

\begin{abstract}
This chapter addresses feminist IR scholarship in Europe on gender and foreign policy. Foreign policy has received comparatively little consideration from feminist scholars and, until recently, the field has been largely gender blind. The chapter discusses feminist scholarship in four key sections, on gender and the idea of 'normative power' Europe; the process of EU enlargement and expansion; the securitization/militarization of foreign policy; and, finally, the emerging literature on 'feminist' foreign policy. The chapter concludes with a discussion of what has been overlooked in the literature so far and what directions research might pursue in the future.
\end{abstract}

Keywords Foreign policy · Feminist foreign policy · Policy-making · Policy implementation · EEAS

J. Thomson $(\bowtie)$

Comparative Politics, University of Bath, Bath, UK e-mail: j.thomson@bath.ac.uk 


\section{INTRODUCTION}

Foreign policy analysis is largely taken to be a "gender-blind field" (Hudson, 2005). As a result, there has been relatively little academic interest in either the descriptive makeup of those making foreign policy decisions or the gendered nature of foreign policy (Smith, 2020). As the previous chapters illustrate, while much feminist academic attention in Europe has been paid to security and defense policy, the gendered nature of the military, international political economy, and international development, the language of foreign policy has received little sustained attention from feminist academia (Debusscher and Manners, 2020, 543; Smith, 2020; Aggestam and True, 2020, 4).

The literature that has been produced in this field has worked to challenge the presumed gender-neutrality of foreign policy (studies), by highlighting the male-dominance of the field; by illustrating gendered differences in public opinion related to foreign policy; and through an exploration of the gendered nature of the policy content of both state and EU foreign policy. As such, literature in the field of gender and foreign policy studies has made key interventions, urging mainstream IR to consider the role of women in foreign policy-making and, more broadly, the gendered ideas which underpin and sustain much of the fundamental work of foreign affairs. Despite this, the gender blindness of much foreign policy analysis (FPA) means that the work on gender and foreign policy has largely grown up in parallel to it, rather than in engagement with it (Smith, 2020). As a result, mainstream IR has yet to take much sustained interest in the ideas explored in this chapter.

This chapter explores what literature has been produced within the European context on gender and foreign policy, beginning with a brief overview of the nature of this work so far. Following this, it then looks at three key areas from the literature on gender and foreign policy-gender and state foreign policy; EU foreign policy; and then finally, the securitization/militarization of foreign policy. It does so largely through a conceptualization of three stages of the policy process-policy-making; policy content; and policy implementation, showing that feminist IR in Europe thus far has largely been focused on the content of foreign policy. It concludes with a discussion of what has been overlooked in the literature on gender and foreign policy so far, what directions research might pursue in the future, and how this focus on one stage of the policy process at the expense of the others might be overcome in subsequent literature. 


\section{Overview}

Research on gender and 'foreign policy' faces difficulties due to the expansive nature of what foreign policy covers. Although in more recent years a body of work is emerging around gender and foreign policy in Europe (particularly with reference to the EU institutions and mechanisms), it remains undertheorized (Debusscher and Manners, 2020, 543; Mos, 2013; Muehlenhoff, 2017, 163). For example, a key edited collection such as Gendering the European Union (Abels and Mushaben (eds), 2012) does not contain an specific chapter about foreign policy. ${ }^{1}$ Although there has been a wealth of work on the EU and gender, the vast majority focuses on the internal policy dynamics of the Union and the influence that membership has on individual state's equality policies. As the below illustrates, much of the work that does exist on gender and foreign policy centers around the EU's external relations and the normative positioning that the EU presents of its actions.

The work which has been produced on gender and foreign policy comes from a broad range of scholars working across IR, but also within political science and sociology, and often intersects with related work from security studies, development studies, and regional/area studies. The relative absence of literature on gender and foreign policy can perhaps be related to much of feminist IR's critical perspective in Europe and its relative reticence to engage with political institutions (Holmes et al., 2018; Thomson, 2019a). Reflecting this disciplinary eclecticism, the literature on gender and foreign policy works from a variety of methodological positions, although it is in the most part qualitatively focused. Some research works explicitly or implicitly through the lens of feminist institutionalism, exploring the relationship between the state and EU architecture and gendered policy-making (Deiana and McDonagh, 2018b; Guerrina and Wright, 2016; Novotná, 2015). Much research also works from a discourse analysis of policy documents produced (David and Guerrina, 2013; Kronsell, 2016a; Kunz and Maisenbacher, 2016); single case-study analysis (Bretherton, 2001); and a body of work develops from deconstructive/poststructural frameworks of analysis (Kronsell, 2016a, b). A

${ }^{1}$ Equally, a key book such as Foreign policies of EU member states: continuity and Europeanisation (2017), edited by some of the key figures in European studies, contains a variety of thematic chapters on European foreign policy but no specific chapter is given over to gender. 
wide range of work addresses gendered differences in attitudes to foreign policy, mostly via social surveys (including Bjarnegård and Melander, 2017; de Boer, 1985; Kentmen, 2010; Togeby, 1994). Although most work adopts gender largely as it applies to the male/female binary, there is a growing interest in masculinity specifically (Kronsell, 2016a, b; Hoijtink and Muehlenhoff, 2019), as well as in the intersection between gender and race in foreign policy and external affairs (Achilleos-Sarll, 2018; Stern, 2011).

The literature discussed in this chapter was searched for via the main scholarly databases (Scopus, etc.) and my institutional library online catalog. This was followed up with a more detailed search on specific authors who had written on this topic, including looking at their institutional webpages and Google Scholar in order to clarify the extent of their research. Although these methods identified some literature in other languages, as detailed below the majority of literature discussed here is in English due to my language limitations and the Anglophone bent of the field. Indeed, most of this subfield has been produced in Western Europe. This is particularly notable in the burgeoning literature on gender and EU external relations, which has predominantly emerged from academics working within the UK and the Netherlands (Beier and Çăglar, 2020; Guerrina and Wright, 2016; Haastrup et al., 2019; Hoijtink and Muehlenhoff, 2019; Muehlenhoff et al., 2020; Slootmaeckers, 2019; Wright and Guerrina, 2020). Equally, developing work on feminist foreign policy has had a strong Swedish bent, ${ }^{2}$ reflecting its origins as a policy agenda (Aggestam and Bergman-Rosamond, 2016, 2019; Aggestam et al 2019; Bergman-Rosamond, 2020). However, there is also interest from the UK (Haastrup, 2020; Thomson, 2019b), and strong research connections between European and Australian academics (Aggestam and True, 2020). The implications of this dominance of Anglophone work and its location primarily in Western Europe are considered further in the final section.

2 Ongoing work on FFP is also strongly influenced by Swedish academia including projects at Lund University (Aggestam and Bergman-Rosamond; Sundström and Zhukova) and the University of Gothenburg (Jezierska and Towns). There is, however, developing work on FFP outside of the Swedish context including projects and work by, amongst others, Thomson (UK), Haastrup (UK), Faerber (UK), True (Australia), Cheung (Germany) and a wide variety of Canadian authors (see International Journal, 2020, 75 : $3)$. 


\section{Gender and State Foreign Policy}

There has been some limited work within European scholarship on gender and states' foreign policy, often focusing on specific events such as Brexit (Haastrup et al., 2019) or overlapping with international development scholarship (see Chapter 6). Selected literature has addressed the gender gap in public opinion on foreign policy within selected European states, including some comparative work (Bjarnegård and Melander, 2017; de Boer, 1985; Kentmen, 2010; Togeby, 1994). Within broader work on foreign policy and FPA, however, there is little sustained engagement with gender. Indeed, a recent article such as Smith's (2020) undertakes the first steps at a comprehensive overview of the literature on women and foreign policy-making. She shows how under-developed the field is, pointing out that only four articles in the history of the leading journal Foreign Policy Analysis have addressed gender directly (132). ${ }^{3}$ The important, but fundamental, nature of this article shows how far work on gender and foreign policy has to go.

Much of the contemporary work on gender and foreign policy has instead developed outside of mainstream FPA literature (Smith, 2020), including growing work which addresses the recent advent of feminist foreign policy (FFP). As such, this work has emerged in parallel to existing mainstream work (responding largely to the feminist moniker), rather than in direct conversation with the concepts and ideas of dominant FPA. So far, it has focused primarily on the contents of the newly developed FFPs seen throughout Europe and beyond, with less consideration given to the political processes of their introduction or their implementation.

FFP originated in Sweden in 2014. It represented a new direction for Swedish foreign policy in its choice of the 'f-word' (Aggestam and Bergman-Rosamond, 2016, 323) but in many ways was a continuation of the state's existing international commitments to women's rights (Ibid; Aggestam and Bergman-Rosamond, 2019; Bergman-Rosamond, 2020; Thomson, 2019b, 2022). Following the Swedish adoption, Canada followed suit with a feminist international assistance policy in 2017. Mexico, France and Spain have also adopted FFP, and Libya and Germany have indicated they will follow. What precisely the feminist descriptor means is debated (Thomson, 2019b, 2022) but, particularly in the

3 This article was published prior to Aggestam and True's Special Issue of Foreign Policy Analysis on Feminist Foreign Policy (2020). 
Swedish case, there is a focus on commitment to liberal international norms and institutions.

FFP is therefore not coming from within the institutions of the EU but rather states. As a result, the focus of study within Europe on gender and foreign policy is shifting from a previous strong interest in the EU architecture (as shown below) to individual nation-states. Much academic literature has focused on the original Swedish case. In their work on Swedish FFP, Karin Aggestam and Annika Bergman-Rosamond (2016) argue that the use of the 'f-word' "elevates" foreign policy in a way that "explicitly seek[s] to renegotiate and challenge power hierarchies and gendered institutions that hitherto defined global institutions and foreign and security policies" (323). Although acknowledging the political problems which may lie in the path of a full implementation of such policy, they argue that FFP stands to make a key contribution to thinking about the ethical nature of foreign policy more broadly, in that it provides " $\mathrm{a}$ more rigorous ethical yardstick than is currently available against which to evaluate the normative and feminist contents of states' international orientations, identities, and concrete policies" (332). In this article, and in their future work on Swedish FFP (2018; 2019; Aggestam et al., 2019; Bergman-Rosamond, 2020), they are interested thus to develop a theoretical framework through which feminist IR and feminist ethics of care might be used to analyze attempts at foreign policy-making.

Aggestam and True (2020) propose a framework for conducting a gendered analysis of foreign policy which allows for comparative research between states' polices. Work within Europe which looks to foreign policy elsewhere argues that it runs the risk of seeing gender only as the sex binary of man/woman (Haastrup, 2020) and that, echoing the discussion of enlargement above, there is a disjoint between the language on gender in foreign policy versus the reality of the domestic situation (Ibid; Thomson, 2019b, 2022). In a more theoretical vein, AchilleosSarll (2018) argues for a necessary conversation between postcolonialism and feminism in order to invigorate foreign policy analysis and highlight the way that foreign policy "should be re-conceptualised as gendered, sexualised and racialised" (45) in all contexts.

\section{EU Foreign Policy}

Work on EU foreign policy represents the largest area within feminist IR scholarship in Europe on gender and foreign policy to date. It can be broadly thought of in three categories-policy-making, analysis of policy 
contents, and finally, policy implementation. As with the work on state's foreign policy described above, the majority of work on gender and EU foreign policy falls into the second category.

In its analysis of policy content, much feminist scholarship in Europe on EU foreign relations takes Ian Manners' understanding of 'normative power Europe' (2002) as its starting point, asking about the place of gender in how the EU presents itself and interacts with the world. There is a broad appreciation in the literature that this normative basis to foreign relations is the way that the EU presents itself (Manners, 2002, 252 ) and that it is keen to be seen to be adopting the role of a 'benevolent teacher' (Van der Vleuten, 2013, 308) when it comes to gender equality and LGBT rights. However, much literature argues that while "equality should be a perfect platform for normative power Europe ... gender issues remain largely invisible" in the EU's external policy (Guerrina and Wright, 2016, 295; Woodward and Van der Vleuten, 2014). A wide range of scholars argue that the EU's claim to be an innovator in gender equality issues, particularly in the area of gender mainstreaming, is largely a projection rather than a reality (David and Guerrina, 2013, Guerrina and Wright, 2016; Mos, 2013; Van der Vleuten, 2013; Woodward and Van der Vleuten, 2014). The literature argues further that the EU consciously adopts the language of gender equality to further its own aims, adopting it instrumentally rather than based around an understanding of rights. Indeed, in their work on the European External Action Service (EEAS), Chappell and Guerrina argue that the EEAS "strategically co-opts gender narratives to promote the interests of the organisation" $(2020,21)$.

The literature further stresses that the EU has competing goals in its gender equality work. Although the EU appears eager to use the rhetoric of gender equality, this masks the fact that its principal guiding force is that of a market logic. The literature shows that the EU has focused on gender equality in employment over other issues (Peto and Manners, 2006; David and Guerrina, 2013; Chappell and Guerrina 2020; Haastrup, Wright and Guerrina, 2019; Woodward and Van der Vleuten, 2014; Van der Vleuten, 2013, 317: also in terms of LGBT rights-Muhlhenhoff, 2017). In a trade-off between market forces and gender equality, scholars argue that the original operating basis of the EU-as a common market-always takes precedence in its external relations.

Woodward and Van der Vleuten argue that the EU "sees itself as an exporter of gender equality norms in two activities": enlargement 
negotiations and external relations $(2014,77)$. Reflecting this, much of the literature on gender and the EU's foreign relations focuses on enlargement and neighborhood policies. A growing body of literature stresses the colonial and racial hierarchy which is implicitly embedded in much of this policy-making and its interest in establishing and reinforcing the boundaries of the EU. It argues that depictions of the 'outside' in EU neighborhood relations policy reify colonial ideas and that "through gendered and racialised codings, the EU neighbourhood is constituted as a backward Other in the official NENP discourse" (Kunz and Maisenbacher, 2016).

As in the above discussion of the EU as a gendered normative power, there is again a strong argument from the literature on enlargement that gender equality has not been fully mainstreamed in the process of enlargement and integration. Bretherton argues that in the process of integration in the 1990s there was an argument made by central figures that "social policy areas such as gender equality and safety at work, should be set aside to facilitate accession" $(2001,69)$. Similarly, Kristofferson et al (2016, 63) also argue that the inclusion of LGBT rights into the process of expansion was relatively late. David and Guerrina argue that there is a high/low politics distinction $(2013,61)$ in the context of the European Neighbourhood Policy in which gender is seen as expendable. Again, echoing the above, this piecemeal approach to gender in EU enlargement is reinforced through its instrumentalization and a focus on an economic understanding of gender equality (David and Guerrina, 2013, 60; Debusscher, 2012; Kunz and Maisenbacher, 2016).

Compared to the analysis of policy content, there is much less consideration of policy implementation and policy-making. There is some limited work on the descriptive nature of the policy-making institutions, which argues that gender mainstreaming has achieved little in a policy sense within the EEAS (reduced to a "tick-box exercise" (Chappell and Guerrina, 2020, 276)), nor in the makeup of the institution (Chappell and Guerrina, 2020; Guerrina and Wright, 2016; Novotná, 2015). Despite several high-profile female leaders, women are severely underrepresented in the EEAS (Novotná, 2015; see also Guerrina and Wright, 2016, 302), suggesting that the institution is struggling with the arguably more basic task of recruiting and retaining female staff, let alone adopting a gendered lens to policy-making.

When the literature turns to consider implementation, there is a strong concern about what the absence or low prioritization of gender in EU 
enlargement will mean internally (David and Guerrina, 2013; Debusscher and Manners, 2020; Guerrina et al., 2018; Mos, 2013). The literature also highlights the hypocrisy of the EU using rhetoric around gender equality in its enlargement policies when internal measures are failing to deliver (in terms of women's representation within the EEAS, Novotná, 2015 and in relation to LGBT rights, Mos, 2013; see also Woodward and Van der Vleuten, 2014).

\section{Securitization/Militarization of Foreign Policy}

Recently, the literature has argued that the gendered normative power of the EU and its external relations are increasingly militarized (Haastrup, Wright and Guerrina, 2019; Hoijtink and Muehlenhoff, 2019; Muehlenhoff, 2017). Again, the literature levels accusations that gender equality is "tolerated" (Deiana and McDonagh, 2018b, 48) so long as it fits into already existing security goals, and is used largely in an instrumental fashion, one in which "gender equality is only a means to an end, not an end in itself" (Muehlenhoff, 2017, 163; see also Guerrina and Wright, 2016, 309; Guerrina, Chappell and Wright, 2018). Haastrup et al. note that although "the EUGS [EU Global Strategy, published in 2016] makes a call for greater gender inclusivity," it does so in order to "further defence cooperation and militarism" $(2019,68)$.

An understanding of gender beyond the male/female binary (particularly in relation to ideas around masculinity) is being given greater consideration in the literature on gender and militarism in the EU, due largely to the overlap and influence of feminist critical security studies. Hoijtink and Muehlenhoff argue that the "current crisis narrative" (2019, 3 ) around migration, the failure of international liberal governance, and the rise of authoritarian rulers allow for "further advancement of militarism and the militarised masculinities associated with it" (Ibid, 12) within the EU's CSDP. Similarly, Kronsell (2016a, b) argues that an 'EU protector masculinity' emerges in the EU's CSDP. Despite the growing literature, Muehlenhoff (2017) points out that although indeed the EU often "conceptualizes gender as a social construct" (163) in its security policies, this is generally reduced to a discussion of men/women.

Again, reflecting links to feminist critical security studies, there has been an increasing focus on the WPS agenda within literature on EU foreign affairs (Chappell and Guerrina, 2020; Deiana and McDonagh, 2018a, b; Guerrina and Wright, 2016; Guerrina, Chappell and Wright, 
2018; Muehlenhoff, 2017). The EEAS appointed a Principal Advisor on Gender in 2015, whose job title also includes reference to WPS (although the role is arguably limited and lacking seniority; Guerrina and Wright, $2016,310-311)$. WPS appears to be one of the key ways in which the EU understands the gendering of foreign policy, reflecting the agenda's dominance in the work of nation-states and transnational actors around the globe. However, and echoing the above, despite the fact that the agenda should meld easily with stated EU norms and values, the EU has been slow to implement it (Guerrina and Weight, 2016). Haastrup et al. note that the EU was largely "absent" $(2019,66)$ from 2000 to 2016, a period in which many European countries worked through multiple National Action Plans. Much literature finds the EU's policy commitments wanting with regard to WPS (Deiana and McDonagh, 2018a, b; Guerrina and Wright, 2016; Guerrina, Chappell and Wright, 2018; Muehlenhoff, 2017) and focused outward with less emphasis on tackling EU organizations and practice (Deiana and McDonagh, 2018a).

\section{What's BEEN OverLOOKED IN EUROPEAN FEMINIST IR SCHOLARSHIP ON FOREIGN Policy and EU External Relations?}

Although the literature is more limited than other areas, European feminist IR scholarship has still had substantial interest in gender and foreign policy, with particular attention paid to EU policy and mechanisms. However, several key oversights remain. Silences on the colonial past of EU states are particularly prescient in this literature (although Manners and Debusscher, 2020 propose a framework to challenge this). Claims on the part of the EU or individual states (particularly Sweden's FFP positioning) to be a normative power need to be more strongly interrogated in the context of the European colonial history. There has also been relatively little work thinking about the interactions of gender and race in these policies (although with some notable exceptions AchilleosSarll, 2018; Debusscher and Manners, 2020). Similarly, intersectionality is adopted in a piecemeal fashion in FFP. There has been little literature exploring what its adoption as an analytical framework might give to our understanding of foreign policy (see Achilleos-Sarll, 2018).

Furthermore, work on foreign policy might engage more with work on migration to explore where the 'foreign' and the 'domestic' begin in 
the continent. Where are the boundaries of Europe? What are the power dynamics at play in foreign policy? How does discussion of gender aid in the construction of the 'inside' and 'outside' in relation to Europe? Indeed, as Manners and Debusscher $(2020,547)$ argue, there is a need to think about these policies from the perspective of those who are on the receiving end. This oversight reflects the geographic origins of much of this work which, as previously shown, is largely emerging in Anglophone literature written in Western Europe with stronger links to other Anglophone regions as opposed to Central or Eastern Europe. Greater consideration within the literature might be given to the issue of who foreign policy is for, and how these voices and perspectives might be captured within academic work.

There is also much to be considered with regard to foreign policy in the context of the resurgence of right-wing populism, nativist politics, and Euroscepticism across the continent. There is a well-developed body of literature on the gendered nature of populism, racism, and xenophobia (Farris, 2017; Towns et al., 2014), but less consideration of how this might shape foreign policy. The context in which this edited collection is written is one of a post-Brexit Europe; an ongoing 'crisis' around migration; the lack of an integrated EU response to the COVID-19 pandemic; and right-wing backlash against gender equality across the continent. Foreign policy in the aftermath of these events will be particularly important (and gendered) and scholarly attention must be paid to it.

Furthermore, the majority of work explored above largely works from an understanding of gender as a sex binary. There has been some interest in masculinity (Kronsell, 2016a, b; Muehlenhoff, 2017; Stern, 2011), but the idea of femininity has been given less consideration. There is much more to be pursued here-particularly ideas about the masculine, 'protective' nature of the EU and intersections with colonial tropes. Although there is a very well-developed body of work on LGBT rights and EU enlargement (Ayoub and Paternotte, 2014; Bilic, 2016; Slootmaeckers, Touquet and Vermeersch, 2016; Slootmaeckers, 2019), there has been less discussion of LGBT issues in relation to foreign policy or development work. Future work might therefore explore what space is given to LGBT rights in foreign policy or in the work of the EEAS.

Finally, many long-established ideas in feminist political science which attempt to explain and understand the gendered natures of government and institutions might be fruitfully employed in foreign policy analysis 
(Smith, 2020, develops a framework for this). An exploration of critical actors; the importance of descriptive representation; the role that women in executive positions have-these might all be used to explore foreign policy. There has been, for example, little consideration of the feminized leadership of the EEAS and the influence that the leadership of Catherine Ashton and Federica Mogherini has had (although see Hartlapp and Blome, 2021; Novotná, 2015). Similarly, the role and influence of Margot Wallström and the development of feminist foreign policy in Sweden might be explored. This absence is especially prominent given the developing work on gender and foreign policy leaders in the US context (Bashevkin, 2019; Hudson and Leidl, 2015).

This blindness to thinking about the descriptive makeup of the policy formation stage reflects the narrow focus that much feminist IR literature has had on foreign policy content. As illustrated in this chapter, feminist IR work on gender and foreign policy in Europe has had less interest in the earlier stages of the policy process, nor the implementation of said policy. Work on gender and foreign policy has been more reactive to specific policy changes (such as FFP and the WPS agenda) rather than proactively and consistently engaging with FPA as a sub-discipline. This also reflects the disciplinary breakdown of the policy process into separate sub-disciplines, with political science taking more interest in the first stage and international development the final. There is therefore an opportunity for more cross-disciplinary work in this area. If the gendered implications of foreign policy are to be more fully understood, there needs to be a desire on the part of scholars to engage with work from different disciplinary, methodological, and epistemological backgrounds.

\section{CONCLUSION}

Although the literature on gender and foreign policy within and concerning Europe is limited in comparison with the attention given to other areas of feminist IR, it advances certain key arguments. Firstly, the EU has been slow to include gendered concerns in all aspects of foreign policy and its external relations, ranging from women's rights to the WPS agenda to LGBT rights. Secondly, the literature argues that when gender is included, it is generally in a narrow or instrumental fashion, with a focus on access to employment or bending gendered concerns to already existent interests. Most recent literature argues that there is a creeping militarization in the EU's discussion of gender in its foreign policy, in part 
a response to a world which is growing more uncertain and in which the type of liberal institutionalism that the EU builds from is coming under stress. At the same time, the advent of FFP, originating within Europe and being especially championed by Sweden, appears to act as a rejoinder to this.

Underpinning this though are key silences, particularly in relation to Europe's colonial legacies, the resurgence of right-wing populism across the continent and gender beyond the male-female binary. The growing critical nature of much of the literature on gender and foreign policy suggests that not only will it continue as an area of interest for feminist IR in Europe but that it will become more interested in such questions. Perhaps more dispiritingly, the existing literature appears to have made little inroads into mainstream FPA work and has largely emerged in parallel to it, rather than in conversation. Moving forward, scholars in this area therefore also carry the burden of trying to encourage the majority of European IR to engage more fruitfully with the ideas and work represented here.

\section{BIBLIOGRAPHY}

Abels, G., and Mushaben, J.M. 2012. Gendering the European Union: New Approaches to Old Democratic Deficits. Basingstoke: Palgrave Macmillan.

Achilleos-Sarll, Columba. 2018. Reconceptualising Foreign Policy as Gendered, Sexualised and Racialised: Towards a Postcolonial Feminist Foreign Policy (Analysis). Journal of International Women's Studies, 19(1), 34-49.

Aggestam, K. and A. Bergman-Rosamond. 2016. Swedish Feminist Foreign Policy in the Making: Ethics, Politics, and Gender. Ethics and International Affairs, 30(3), 323-334.

Aggestam, Karin and Annika Bergman-Rosamond. 2019. Feminist Foreign Policy 3.0: Advancing Ethics and Gender Equality in Global Politics. The SAIS Review of International Affairs, 39(1), 37-48.

Aggestam, Karin, Annika Bergman Rosamond, and Annica Kronsell. 2019.

Theorising Feminist Foreign Policy. International Relations 33(1), 23-39.

Aggestam, Karin and True, Jacqui. 2020. Gendering Foreign Policy: A Comparative Framework for Analysis. Foreign Policy Analysis, 16(2), 143-162.

Ayoub, P.M., and Paternotte, D. (eds.). (2014). LGBT Activism and the Making of Europe: A Rainbow Europe? Basingstoke, England: Palgrave Macmillan.

Bashevkin, S. 2019. Women as Foreign Policy Leaders: National Security and Gender Politics in Superpower America. OUP

Beier, Friederike and Çağlar, Gülay. 2020. Depoliticising Gender Equality in Turbulent Times: The Case of the European Gender Action Plan for External Relations. Political Studies Review, 18(3), 426-443. 
Bergman-Rosamond, Annika. 2020. Swedish Feminist Foreign Policy and "Gender Cosmopolitanism. Foreign Policy Analysis. [online].

Bilic B (ed.). 2016. LGBT Activism and Europeanisation in the Post-yugoslav Space: On the Rainbow Way to Europe (pp. 1-22.). Basingstoke: Palgrave Macmillan.

Bjarnegård, Elin and Melander, Erik. 2017. Pacific Men: How the Feminist Gap Explains Hostility. Pacific review, 30(4), 478-493.

Bretherton, C. 2001. Gender Mainstreaming and EU Enlargement: Swimming Against the Tide? Journal of European Public Policy, 8(1), 60-81.

Chappell, Laura andGuerrina, Roberta. 2020. Understanding the Gender Regime in the European External Action Service. Cooperation and Conflict, 55(2), 001083671989529-280.

David, Maxine and Guerrina, Roberta. 2013. Gender and European External Relations: Dominant Discourses and Unintended Consequences of Gender Mainstreaming. Women's Studies International Forum, 39, 53-62.

De Boer, C. 1985. The Polls: The European Peace Movement and Deployment of Nuclear Missiles. Public Opinion Quarterly 49(1), 119-32.

Debusscher, P. 2011. Mainstreaming Gender in European Commission Development Policy: Conservative Europeanness?. Women's Studies International Forum, 34(1), 39-49.

Debusscher, P. 2012. Mainstreaming Gender in European Union Development Policy in the European Neighborhood, Journal of Women, Politics \& Policy, $33(4), 322-344$.

Debusscher, P. 2013. Gender Equality in European Union Development Policy: Incorporating Women's Voices or Confirming Hierarchies? Afrika focus, $26(2), 31-45$.

Debusscher, Petra and Manners, Ian. 2020. Understanding the European Union as a Global Gender Actor: The Holistic Intersectional and Inclusive Study of Gender in External Actions. Political studies review, 18(3), 410-425.

Deiana, Maria-Adriana \& McDonagh, Kenneth. 2018a. Translating the Women, Peace and Security Agenda into EU Common Security and Defence Policy: Reflections from EU Peacebuilding. Global Society: Journal of Interdisciplinary International Relations, 32(4), 415-435.

Deiana, Maria-Adriana and McDonagh, Kenneth. 2018b. 'It is Important, But...': Translating the Women Peace and Security (WPS) Agenda into the planning of EU Peacekeeping Missions. Peacebuilding, 6(1), 34-48.

Elgström, O. 2000. 'Norm Negotiations: The Construction of New Norms Regarding Gender and Development in EU Foreign Aid Policy. Journal of European Public Policy, 7(3), 457-476.

Engberg-Pedersen, L. 2016. Policy Making in Foreign Aid: Gender Equality and Danish Development Policy. The Journal of Development Studies, 52(7), 933-949. 
Farris, Sara R. 2017. In the Name of Women's Rights: The Rise of Femonationalism. Durham, N.C.; London: Duke UP.

Galligan, Y. and S. Clavero. 2012. 'Gendering Enlargement of the EU. Iin G. Abels and J. M. Mushaben (Eds.), Gendering the European Union (pp. 104126). Basingstoke: Palgrave Macmillan.

Guerrina, Roberta, Chappell, Laura and Wright, Katharine A.M. 2018. Transforming CSDP? Feminist Triangles and Gender Regimes. Journal of common market studies, 56(5), 1036-1052.

Guerrina, Roberta and Wright, Katharine A.M. 2016. Gendering Normative Power Europe: Lessons of the Women, Peace and Security Agenda. International affairs, 92(2), 293-312.

Haastrup, Toni. 2020. "Gendering South Africa's Foreign Policy: Toward a Feminist Approach?" Foreign Policy Analysis. [online].

Haastrup, Toni, Wright, Katharine A.M andGuerrina, Roberta. 2019. Bringing Gender In? EU Foreign and Security Policy after Brexit. Politics and governance, $7(3), 62-71$.

Hadfield et al. 2017. Foreign Policies of EU Member States: Continuity and Europeanisation. Abingdon: Routledge.

Hartlapp, Miriam and Agnes Blome. 2021. Women at the Top of the European Commission-Drivers and Barriers, Swedish Institute for European Policy Studies, Women at the Top of the European Commission-Drivers and Barriers (sieps.se). Accessed April 15, 2021.

Hoijtink, Marijn and Muehlenhoff, Hanna L. 2019. The European Union as a Masculine Military Power: European Union Security and Defence Policy in 'Times of Crisis.' Political studies review, 18(3), 362-377.

Holmes, Georgina et al. 2018. Feminist Experiences of 'Studying Up': Encounters with International Institutions. Millennium, 47(2), 210-230.

Hudson, Valerie M. 2005. Foreign Policy Analysis: Actor-Specific Theory and the Ground of International Relations. Foreign Policy Analysis 1 (1): 1-30.

Hudson, Valerie M. and Patricia Leidl. 2015. The Hillary Doctrine: Sex and American Foreign Policy New York: Columbia University Press.

Jezierska, Katarzyna and Ann Towns. 2018. Taming Feminism? The Place of Gender Equality in the 'Progressive Sweden' Brand. Place Branding o Public Diplomacy 14(1), 55-63.

Jezierska, Katarzyna. 2021. Incredibly Loud and Extremely Silent. Feminist Foreign Policy on Twitter. Cooperation \& Conflict. [online]. Accessed April $21,2021$.

Kentmen, C., 2010. Bases of Support for the EU's Common Foreign and Security Policy: Gender, Attitudes toward Economic Integration, and Attachment to Europe. International political science review, 31(3), 285-299.

Kristofferson, Matthias, Björn von Roozendahl and Lilit Poghosyan. 2016. European Integration and LGBTI Activism: Partners in Realising Change? In K. 
Slootmaeckers, H. Touquet, and P. Vermeersch. 2016. The EU Enlargement and Gay Politics: The Impact of Eastern Enlargement on Rights, Activism and Prejudice. London: Palgrave Macmillan.

Kronsell, A. 2016a. Sexed Bodies and Military Masculinities. Men and Masculinities, 19(3), 311-336.

Kronsell, A. 2016b. The Power of EU Masculinities: A Feminist Contribution to European Integration Theory. Journal of Common Market Studies, 54(1), 104-120.

Kunz, Rahel and Maisenbacher, Julia. 2016. Women in the eighbourhood: Reinstating the European Union's Civilising Mission on the Back of Gender Equality Promotion? European Journal of International Relations, 23(1), $122-144$.

Locher, B. 2012. Gendering the EU Policy Process and Constructing the Gender Acquis. In G. Abels and J. M. Mushaben (Eds.), Gendering the European Union (pp. 63-84). Basingstoke: Palgrave Macmillan.

Manners, I. 2002. Normative Power Europe: A Contradiction in Terms? Journal of Common Market Studies, 40(2), 235-258.

Mos, M. 2013. Conflicted Normative Power Europe: The European Union and Sexual Minority Rights. Journal of Contemporary European Research 9 (1), 78-93.

Muehlenhoff, H.L. 2017. Victims, Soldiers, Peacemakers and Caretakers: The Neoliberal Constitution of Women in the EU's Security Policy. International Feminist Journal of Politics, 19(2), 153-167.

Muehlenhoff, H.L.M., 2019. Neoliberal Governmentality and the (De)politicisation of LGBT Rights: The Case of the European Union in Turkey. Politics, 39(2), 202-217.

Muehlenhoff, H.L. (Guest ed.), Welfens, N.P.M. R. (Guest ed.), and van der Vleuten, A. (Guest ed.). 2020. Slipping Off or Turning the Tide? Gender Equality in European Union's External Relations in Times of Crisis. Political Studies Review, 18(3), 322-459.

Novotná, Tereza. 2015. Women in the EEAS and EU Delegations: Another PostWestphalia Change? in European Diplomacy Post-Westphalia? In Jozef Bátora and David Spence (Eds.), The European External Action Service: European Diplomacy Post-Westphalia (pp. 426-436). Palgrave Macmillan, Basingstoke.

Peto and Manners. 2006. "he European Union and the Value of Gender Equality. In Lucarelli, Sonia, Manners, Ian (Eds.), Values and Principles in European Union Foreign Policy. Florence: Routledge.

Richey, Lisa Ann. 2001. In Search of Feminist Foreign Policy Gender, Development, and Danish State Identity. Cooperation and Conflict, 36(2), 177-212.

Šimáková, Michaela Anna. 2017. The EU's External Engagement in the Promotion of Gender Equality. In C. Damro, S. Gsteohl and S. Schunz. 2018. 
The European Union's Evolving External Engagement: Towards New Sectoral Diplomacies?. London: Routledge.

Slootmaeckers, K., Touquet, H., and Vermeersch, P. 2016. The EU Enlargement and Gay Politics: The Impact of Eastern Enlargement on Rights, Activism and Prejudice 1st ed. London: Palgrave Macmillan UK: Imprint: Palgrave Macmillan.

Slootmaeckers, K. 2019. Constructing European Union Identity through LGBT Equality Promotion: Crises and Shifting Othering Processes in the European Union Enlargement. Political studies review, 18(3), 147892991987762-361.

Smith, Karen E. 2020. Missing in Analysis: Women in Foreign Policy-Making. Foreign Policy Analysis, 16, 130-141.

Stern M. 2011. Gender and Race in the European Security Strategy: Europe as a 'Force for Good'? Journal of International Relations and Development, 14(1), 28-59.

Thiel M. 2015. Transversal and Particularistic Politics in the European Union's Antidiscrimination Policy: LGBT Politics under Neoliberalism. In M.L Picq and M. Thiel (Eds.), Sexualities in World Politics: How LGBTQ Claims Shape International Relations (pp.75-91). London; New York: Routledge.

Thomson, J. 2019a. The Women, Peace, and Security Agenda and Feminist Institutionalism: A Research Agenda. International Studies Review, 21 (4), $598-613$

Thomson, J. 2019b. What's so Feminist about Feminist Foreign Policy? International Studies Perspectives, 21 (4), 424-437

Thomson, Jennifer. 2022. Gender norms Global Hierarchies and the Evolution of Feminist Foreign Policy. European Journal of Politics and Gender. https://doi.org/10.1332/251510821X16354220233761. OnlineFirst - https://www.ingentaconnect.com/content/bup/ejpg/pre-prints/con tent-ejpgd2000038

Togeby, Lise. 1994. The Gender Gap in Foreign Policy Attitudes. Journal of Peace Research, 31(4), 375-392.

Towns, A., Karlsson, E., and Eyre, J. 2014. The Equality Conundrum: Gender and Nation in the Ideology of the Sweden Democrats. Party Politics, 20(2), 237.

True, J. 2009. Trading-in Gender Equality: Gendered Meanings in EU Trade Policies. In E. Lombardo, P. Meier and M. Verloo (Eds.), The Discursive Politics of Gender Equality: Stretching, Bending and Policymaking (pp. 121137). London and New York: Routledge.

Van der Vleuten A. 2013. Gender Mainstreaming in EU-SADC Relations: The Capabilities-Expectations Gap. In: Boening A, Kremer J-F and Van Loon A (Eds.), Global Power Europe. Policies, Actions and Influence of the EU's External Relations (pp. 305-320). Heidelberg: Springer. 
Woodward, A.E. and Vleuten, J.M. van der. 2014. EU and the Export of Gender Equality Norms: Myth and Facts. In A. van der Vleuten, A. van Eerdewijk and C. Roggeband (Eds.), Gender Equality Norms in Regional Governance. Transnational Dynamics in Europe, South America and Southern Africa (pp. 67-92). Basingstoke, UK: Palgrave MacMillan.

Wright, Katharine A.M, and Guerrina, Roberta, 2020. Imagining the European Union: Gender and Digital Diplomacy in European External Relations. Political studies review, 18(3), 393-409.

Open Access This chapter is licensed under the terms of the Creative Commons Attribution 4.0 International License (http://creativecommons.org/licenses/ by $/ 4.0 /$ ), which permits use, sharing, adaptation, distribution and reproduction in any medium or format, as long as you give appropriate credit to the original author(s) and the source, provide a link to the Creative Commons license and indicate if changes were made.

The images or other third party material in this chapter are included in the chapter's Creative Commons license, unless indicated otherwise in a credit line to the material. If material is not included in the chapter's Creative Commons license and your intended use is not permitted by statutory regulation or exceeds the permitted use, you will need to obtain permission directly from the copyright holder.

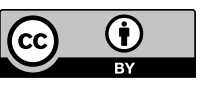

